\title{
Emperors and Councillors: Imperial Representation between Republic and Empire
}

\author{
Olivier Hekster \\ Introduction: Rulers and Ruling Circles
}

No monarch rules on his own. Even the most unmitigated autocrat needs people to undertake administrative roles, sit as judges, command armies, and support the pomp and splendour with which rulers surround themselves. Yet, the status that these supporting actors have can vary wildly. On one end of the spectrum are people who wholly belong to the monarch and depend on his whims for their position. The most eloquent description of that extreme is probably in Kapuscinski's semi-documentary description of the court of Haile Sellasie:

The faction of 'personal people' was a peculiarity of our regime, created by the Emperor himself. His Supreme Majesty, a partisan of a strong state and centralised power, had to lead a cunning and skilful fight against the aristocratic faction, which wanted to rule in the provinces and have a weak, pliable Emperor. But he could not fight the aristocracy with his own hands, so he always promoted into his circle, as representatives of the people, bright young men from the lowest orders, chosen from the lowest ranks of the plebeians, picked often on little more than a hunch from the mobs that surrounded his majesty whenever he went among the people. These 'personal people' of the emperor, dragged straight from our desperate and miserable provinces into the salons of the highest courtiers - where they met the undisguised hatred of the long-established aristocrats - served the emperor with an almost indescribable eagerness, indeed a passion, for they had quickly tasted the splendours of the Palace and the evident charms of power, and they knew that they had arrived there, come within reach of the highest state dignities, only through the will of His Highness. It was to them that the Emperor would entrust the positions requiring greatest confidence. ${ }^{1}$

1 Kapuscinski (1978) 30. 
At the other side of the spectrum is, by implication, a monarch interacting with a much more self-contained group of advisors, who hold their position by long-established patterns. Examples of weak rulers effectively outranked by powerful aristocratic courtiers are abound throughout history. Yet, not only weak rulers are confronted by self-sufficient surrounding circles. How does one deal with a situation in which both ruler and advisors have a strong institutional embedding? How then does one present the ruler and aristocracy? In other words, how does the institutional basis of the people surrounding a monarch influence the representations of the monarch and his advisors? If, as argued in the introduction to this volume, representation is constructed through making representative claims, rather than mirroring a reality, surely the importance of embedding would feature such claims. This chapter looks at imperial Roman representation, as a case study to explore competing claims of representation of rulers and the circles surrounding them.

\section{Absent Emperorship in a Senatorial World}

There were no Roman emperors and yet the emperor formed the centre of the world. When Roman sole rule was shaped under the first emperor Augustus, he had the negative example of his adoptive father Caesar in mind. The latter was assassinated for being too openly monarchical, so his adoptive son formulated his position of sole rule over a long trajectory in which he accumulated various honours and powers step-by-step. Important in this process was that he did not seem to acquire these powers actively (to avoid appearing monarchical) but that they were bestowed upon him by existing (Republican) institutions. ${ }^{2}$ As stated in the much-cited Res Gestae Divi Augusti, 'the accomplishments of the deified Augustus', which were inscribed in bronze and marble throughout the empire after the emperor's death in $14 \mathrm{AD}$ :

In my sixth and seventh consulships [ 28 and $27 \mathrm{BC}$ ], after I had put an end to civil wars, although by everyone's agreement I had power over everything (potens rerum omnium), I transferred the state from my power into the control of the Roman senate and people. For this service, I was named Augustus by senatorial decree, and the doorposts of my house were publicly clothed with laurels, and a civic crown was fastened upon my doorway, and a golden shield was set up in the Julian senate house; through an inscription on this shield the fact was declared that the Roman senate

2 Hodgson (2016) 264-65. 
and people were giving it to me because of my valour, clemency, justice and piety. After this time, I excelled everyone in influence (auctoritas), but I had no more power (potestas) than the others who were my colleagues in each magistracy. ${ }^{3}$

The passage is much discussed, with most attention going to the accuracy of the auctoritas/ potestas statement, and the meaning of auctoritas in this context. ${ }^{4}$ Yet equally striking is the emphasis in the passage on the ruler as a passive figure. All the powers were given to him, and in the list of honours the golden shield in the senate house took pride of place (see Figure 2.1). The senate house itself was renamed after Julius Caesar (who rebuilt it after it was demolished by fire) showing the continuous ambiguity of Augustus's representation. In the heart of Republican institutions, renamed after the founder of what would become an imperial dynasty, a golden shield marked that one person now outshone everyone else. But that same shield formulated what the new ruler also proclaimed elsewhere: that his extraordinary position was based on senatorial acclamation. He was "simply" a more prominent member of the elite. Yet, as one of the foremost scholars on imperial history remarked over thirty years ago with wonderful irony, most people in Rome were "probably not clever enough to read it as a senatorial document." ${ }^{5}$

The mixed message that the new ruler was just a superior senator (the 'first senator', or princeps), but at the same time a recognisable monarch, was visible throughout Rome. ${ }^{6}$ A massive mausoleum celebrated the new-founded dynasty, but made references to republican precedents. A new monumental Forum celebrated the young monarch, by placing him in a line with a number of senatorial heroes. And even the imperial residence showed these two facets of imperial representation. Augustus extended an existing senatorial house on the Palatine - the location of many of the elite residences - to his purpose, and his second-century biographer Suetonius emphasised the modesty of this new house. To an extent, Augustus's house seems to only have appeared modest in retrospect, but its more monumental aspects could all be argued away by pointing at precedents, and because the most ornamental parts were dedicated to various Roman gods. ${ }^{7}$ Augustus's house was linked to a new shining temple for Apollo, near the historical hut of Rome's founder Romulus, and in

3 RGDA 34, trans. Cooley (2009) 98-99, with commentary on 256-72.

4 Rowe (2005) 80-84.

5 Millar (1984).

6 Hekster (2011) 111-24.

7 Raimondi Cominesi (2018); Hekster (2006). 


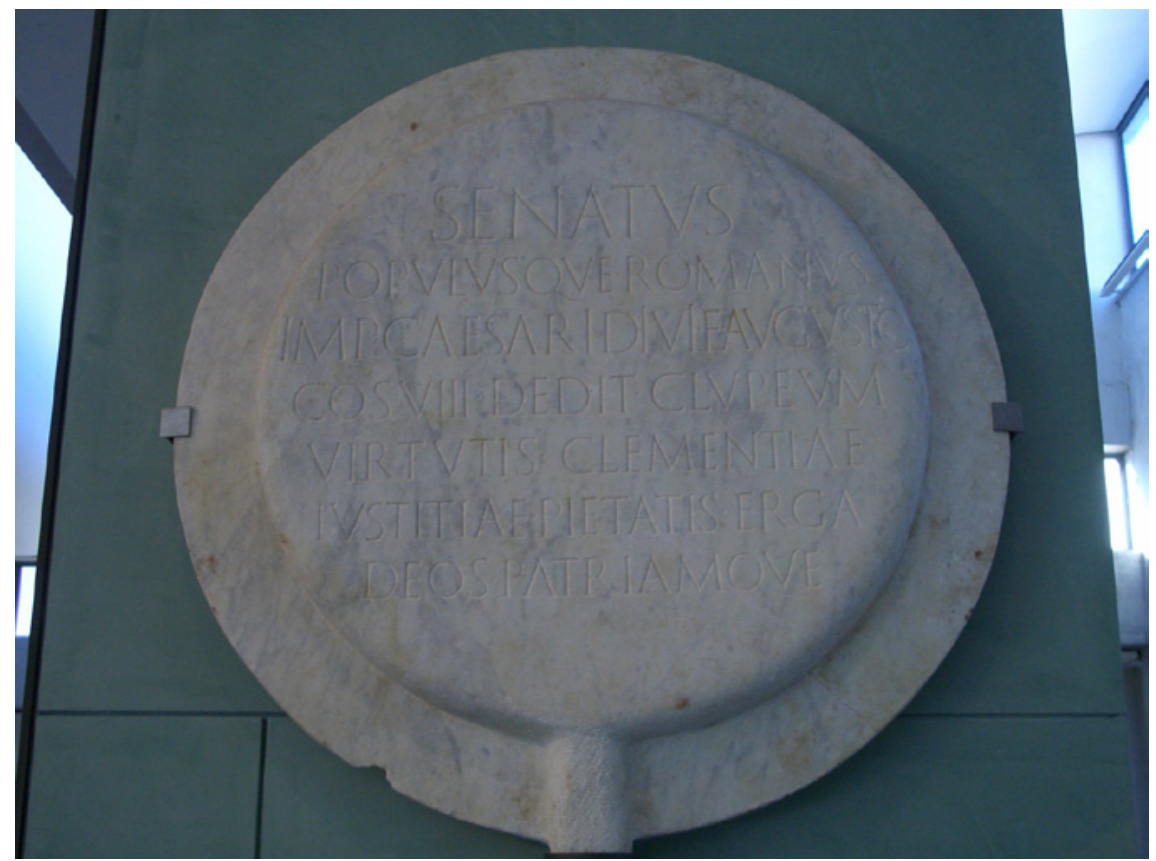

FIGURE 2.1 A Clipeus virtutis (26 BC) showcasing the honours bestowed upon Augustus by the Senate. Source: Wikimedia commons, photo by Maarjaara (CC BY 2.0). [accessed online 28.02.2019: <https://commons.wikimedia.org/wiki/File:Clipeus_ virtutis_-_Augusto_-_Arles.jpg >].

the vicinity of a famous temple to Magna Mater. ${ }^{8}$ This showed the emperor's near-divine prominence, but could be presented as honourable links to Rome's famous past and present. Many senators were Augustus's neighbours, and some of them lived in houses which were strictly speaking comparable. But the overall impression of his house was very different from theirs.

Representation is more than words, images, and buildings. At a performative level, too, the ambiguous position of the Roman ruler as simultaneously a representative but superior senator and a near omnipotent emperor becomes clear. An important aspect of Roman Republican social interaction consisted of fairly formalised series of meetings, of which formal dinner and the morning reception (salutatio) were the more important ones. At the salutatio, clients could pay respect to their (senatorial) patron and ask his advice or support. Houses were set up for the ceremony, with sufficient room in the atrium or vestibulum for groups of clients to wait, whilst more prominent clients or

8 On the Apollo temple as a "golden temple" see Zink (2009). On the link between Augustus's house and the temple, see still Zanker (1987) 59-6o. 
friends (amici) were being received. As any senator, the emperor would receive his clients, but amongst his "friends" were increasing numbers of prominent senators. This increasingly made the imperial salutation into a social and political ritual, which distinguished people's rank and relationship to the emperor. $^{9}$ The performance also became more complex: rather than the earlier handshake, it became possible to kiss the emperor on hand, chest, or knee, or be embraced by him. Different reactions reflected a different relationship, and court officials (admissionales) were appointed to manage the event.

Likewise, being invited to official dinners became a sign of status, and the dinners themselves varied widely in scale and ostentatiousness. Being invited to a more intimate dinner bestowed prestige. So, although the imperial events were similar to senatorial events, the scale and consequences were very different. The result was the increasing institutionalisation of access to the court for so-called imperial friends (amici), rather than for advisors in their role of senator. ${ }^{10}$ Importantly, those who for whatever reasons were personally close to individual emperors could increasingly gain systematic influence.

Yet, whilst such institutionalised social gatherings highlighted the superior position of the emperor, it also suggested the importance of regular meetings with councillors. Though the form of meetings made clear who held social prestige, the very fact of those meetings showed that the ruler was still held by the convention to listen to his advisors. This concept of the Roman emperor as a sort of superior servant, who was present for his advisors and even had to listen to his subjects at large continued for a long time, and is illustrated by a famous anecdote: the third-century senator and historian Cassius Dio writes how the emperor Hadrian (117-138) was approached on a journey by a woman who asked him a question. When the emperor replied that he did not have time, the woman stated "then stop being emperor." One of the main roles of the Roman emperor was to respond to petitions, and "administrate" the Empire like senators had done before. ${ }^{11}$ An emperor could, at his own peril, ignore a random passer-by. Formal councillors and other (more or less) official members of the court could not be ignored at all. Senior senators and a range of magistrates were part of the court through their function. Emperors could, of course, execute and exile such senators and magistrates, and so face constraints which court-life imposed on them, but they would then need to be re-

$9 \quad$ Winterling (1999) 117-44.

$10 \quad$ Winterling (1999) 161-91.

11 Dio, 69.6.3. On the Roman emperor as a responsive figure, see the monumental book by Millar (1992). 
placed by other, similar, councillors. ${ }^{12}$ The emperor needed to publicly interact with his councillors, and show them due reference.

One final form of representation that is indicative for the powerful position of elite councillors in the Roman world is that of literary reflections on individual emperors and on emperorship. Succinctly put: emperors explicitly ruling with senators were described positively, those explicitly ruling over senators were portrayed in negative terms. This, again, shows the strong institutional basis of those senators. Roman historiography, moreover, was systematically written by the Roman elite, mostly by senators. It is unexpected that their texts have a strong senatorial basis. ${ }^{13}$ Yet, it was not only senators who described a form of emperorship in which the relation between the ruler and his councillors was a benchmark for good rule. Other authors, too, saw "aristocratic rule" as the best way to guarantee successful emperorship. ${ }^{14}$

Even emperors themselves seem to have often incorporated such a point of view and interpreted their basis of power in similar light. The famous Meditations of Marcus Aurelius (r. 160-180) include a number of passages in which the emperor reminds himself not to aim for too exalted a status, to "take care that you are not made into a Caesar, that you are not dyed with this dye; for such things happen" (6.30), to "speak both in the senate and to every man, whoever he may be, appropriately" (8.30), and to "stop and take the best advisers [...] if you do not see clear" (10.12). Similarly, the wonderful Caesares by the emperor Julian the Apostate (r. 361-363), a satirical account of the election of the best emperor by the gods, is ironical about much, but not about the exalted status of the ultimate winner Marcus Aurelius, whose temperance and philosophical way of life are praised. It also praises the very pro-senatorial Nerva (r. 96-98): "Very mild were his manners, most just his dealings" (311g). Augustus is praised for the role he played in legislation, with explicit reference to the way he was advised to administer an empire (325-c-d).

In contrast, emperors who ruled openly monarchical were inevitably described as monsters. Prime examples are Caligula, Nero, Domitian, Commodus and Elagabalus. All of whom are blamed for excessive behaviour, inevitably including ridiculing senators and appointing unsuited advisors. Famously, Caligula threatened to appoint his horse Incitatus to the consulship. ${ }^{15}$ Commodus is said to have considered someone a close friend because he had "a penis larger than even most animals,"16 and he made the freedman M. Aurelius Cle-

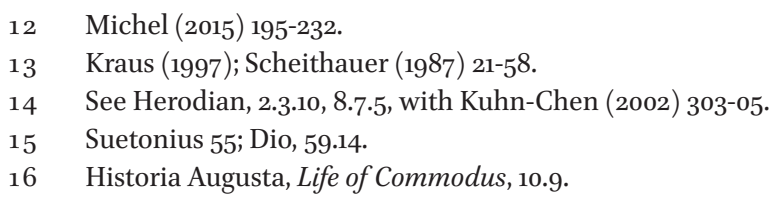


ander one of the more powerful people in the empire, outranking senatorial advisors. Nero's downward path is almost inevitably heralded in by the dismissal of his senatorial advisor Seneca, who is then forced to commit suicide. So dominant is this view, that later authors have often accepted it at face value. Prime of place goes to a famous statement by Edward Gibbon (1737-1794), who describes the years "from the death of Domitian to the accession of Commodus" (96-180) as the "most happy and prosperous" period in history, mainly because:

The forms of the civil administration were carefully preserved by Nerva, Trajan, Hadrian and the Antonines, who delighted in the image of liberty, and were pleased with considering themselves as the accountable ministers of the laws. Such princes deserved the honour of restoring the republic had the Romans of their days been capable of enjoying a rational freedom. ${ }^{17}$

Though recent literature has firmly argued against easy acceptance of this point of view, popular perception has not really changed: ignoring the senatorial elite would have dire consequences for imperial reputations.

\section{Councillors in an Imperial World}

Emperors could not easily ignore senators. At the same time, senatorial roles as councillors and magistrates changed markedly during the empire. Though senators remained important in the administration and organisation of the Empire (as governors, priest, holders of various Roman magistracies, and generals), they increasingly did so under the direct command of the emperor. At an informal level, it was clear that disobeying an emperor who held the monopoly of violence could be dangerous, but at a formal level too, important posts were regularly bestowed upon individuals by imperial appointment. Before there was an emperor, senatorial considerations carried much authority. If senators reached consensus, their advice was invariably followed by the peoples' assemblies who technically decided on laws. After the reign of Augustus, senatorial decrees formally took on legal status, but this boost of their formal powers was only minor compensation for the loss of informal authority. ${ }^{18}$ In the Republic, senators' status was so clear, that formal powers were

\footnotetext{
$17 \quad$ Gibbon (1776) chapter 4.

18 Talbert (1996) 324-37.
} 
less important. Under the emperors, the role of the senate become more prescribed. The senate still represented an institution of great power, and at occasions, for instance when emperors were away from Rome for longer periods of time, they even seemed to represent supreme power. Yet, it had become rapidly clear that senators could no longer rule without an emperor - from early in the Empire on, the question at the death of an emperor was not if but by who he would be replaced. ${ }^{19}$

So how could senators retain their standing, and increase their influence? The most important way, as suggested above, was by proximity to the ruler. Much of this could be at the whim of the monarch and at an informal level. Here too, however, some sort of institutionalisation took place. From the early empire onwards, emperors made use of a so-called concilium principis 'council of the emperor', much like family councils had been normal in the Republic, as had been the practice by senior magistrates to ask advice on judicial questions from a concilium. ${ }^{20}$ At the beginning of imperial rule, the council consisted of senators drawn by lot, but appointments to this council by the emperor rapidly established itself as the norm. Rather than being a permanent body, the council could be called together by the emperor at a case-by-case basis. Membership could shift from one council to the next, depending on specific expertise. ${ }^{21}$ Already during the reign of Tiberius (r. 14-37), non-senators were asked to be part of an imperial consilium. This was a problem for senators, who lost easy access to the emperor and status and in this way. Increasingly, discussing matters in consilium principis came to represent the way in which emperors could show that they listened to their councillors, effectively sidestepping the senate as a body. "Good" emperors still filled their councils with senior senators and high-ranking other members of the elite, but nothing stopped an emperor from excluding senators from his advisory board. ${ }^{22}$ That was one way for him to represent himself as an emperor who listened to his councillor whilst picking his advisors himself. This, then, seriously weakened the institutional basis of the senate as representatives of power.

It was easier for an emperor to exclude senators from his councils when he was traveling in the provinces than when he was in Rome. He could simply argue that there were fewer senators at hand, and that members of the local

\footnotetext{
19 Wiedemann (1996) 198-209.

20 Aulus Gellius, NA 17.21; Valerius Maximus. 5.9.1; Seneca, Clem. 1.15; Cicero, Att. 4.2.5.

21 Eck (2000) 195-213; Crook (1955) 26, 105.

22 Cf. for instance the consilium principis of Marcus Aurelius (r. 161-180) in 177, which included five former consuls, with the one of his son Commodus in 186/7, which does not mention any senators, but includes a freedman: Eck (1997) 7-8, 13 .
} 
(non-senatorial) elite had more local expertise. ${ }^{23}$ At the same time, the senate could more easily be represented as body of supreme power when the emperor was in the provinces for a longer period of time. A travelling emperor, in this way, both limited and enhanced the position and status of the senate. But even when the senate as an institution had relative leeway, individual senators who made up that institution were still beholden to the emperor. By the second century AD, its composition had also changed markedly, with a far larger number of senators from outside the Italian peninsula, increasingly from the Eastern part of the Empire; a closer reflection of the composition of the empire. ${ }^{24}$ Good news for some, of course, but not quite so good for those Roman senatorial families who for generations had dominated the senate, but were now pushed towards the periphery of power.

All these elements together show that though the notion of Roman emperorship as tempered by senatorial advice remains strong, the balance increasingly shifted towards advisors as supporting actors who belonged to the monarch. Yet, they were still represented as having status and power in their own right. Here, we see the same process as we saw above with senatorial recommendations: when the authority of the senate diminished, senatorial edicts formally became law. Likewise, the role of the consilium principis became formalised when emperorship became more openly monarchical. From the reign of Constantine (r. 306-337) onwards the council was renamed as consistorium. Its procedures became formalised as was, to an extent, its membership. There were now ex officio members, but that only marginally hid the fact that the emperor could (and did) still co-opt anyone he wanted. ${ }^{25}$ At the same time, Constantine created a new Senate in Constantinople, and increased the number of senators enormously, raising it from about six hundred to, ultimately, some two thousand. ${ }^{26}$ This is likely to have diminished the entry threshold to the senate, and with it senatorial standing. It may be more than coincidental that the sole surviving letter of Constantine to the senate, addressed it as 'his own senate' (senatui suo). The possessive pronoun is telling. ${ }^{27}$ Notwithstanding the diminished status of individual senators, the term "consistorium," like "senate" and to a lesser extent "concilium," would for a long time retain the aura of power, and be used by popes and princes to denote institutionalised advi-

\footnotetext{
23 On the Roman emperor as a travelling ruler, see still Halfmann (1986).

24 Halfmann (1979).

25 Ammianus Marcellinus, 15.5, 16.7-8, 30.6.2, with the commentary of Boeft (2015) 140-41; Codex Justinianus 1.14.8.

26 Näf (1995) 13-14.

$27 \quad$ Millar (1992) 354 n. 94. Cf. CIL 6.1873.
} 
sors. Yet, often, as in Rome, the presumed power of these institutions was a representative claim, rather than mirroring a reality.

\section{Emperors, Councillors, and Imagery}

Roman emperors, it appears, were on a tightrope as to whether they represented themselves as dependent on their councillors or superior to them. Over time, political status of senators, the most institutionalised type of councillors, diminished. Yet, political support by these senators remained important. Senatorial acclamation was still an expected element of taking up the purple. In the third century, during substantial parts of which the Roman empire was under great military pressure, this practice was not always upheld. The more important acclamation in this period was by the troops. Military success was the surest base of power. Even so, only few rulers ignored the possibility to be acclaimed by senators. That senators had little choice in the matter does not diminish the symbolic importance of their role. Legitimacy was still bestowed upon a ruler by senatorial supports. Senators therefore retained an important role in imperial display. They were, for instance, the first group following the imperial family at emperors' funerary processions. ${ }^{28}$

Monumental art also continued to show emperors surrounded by senatorial advisors. In one of the more famous historical reliefs from ancient Rome, the so-called Ara Pacis, Augustus is depicted alongside senators in a sacrificial procession (see Figure 2.2). The emperor is taller than those surrounding him and followed by a group of priests (the flamines) but he does not particularly stand out. Three centuries later, the similarities and differences with another wellknown monument are striking. The so-called Decennalia base, which was erected in $303 \mathrm{AD}$, when the emperor Diocletianus visited Rome for the first time in twenty years of rule (r. 284-305), also shows a procession of Roman senators. The emperor, however, is on another side of the base, sacrificing in the presence of the Genius (divine spirit) of the Senate (see Figure 2.3). The link to senatorial councillors is retained, but the emperor is secluded at the same time. Likewise, on the near-contemporary reliefs of the so-called Arch of Constantine (dedicated in $315 \mathrm{AD}$ ), the emperor is explicitly depicted among senators, but clearly holds a superior position (see Figure 2.4). Noticeably, some of the spolia (reused sculpture, in this case from the second century AD) on the same arch show emperor and senators in a more egalitarian context. 


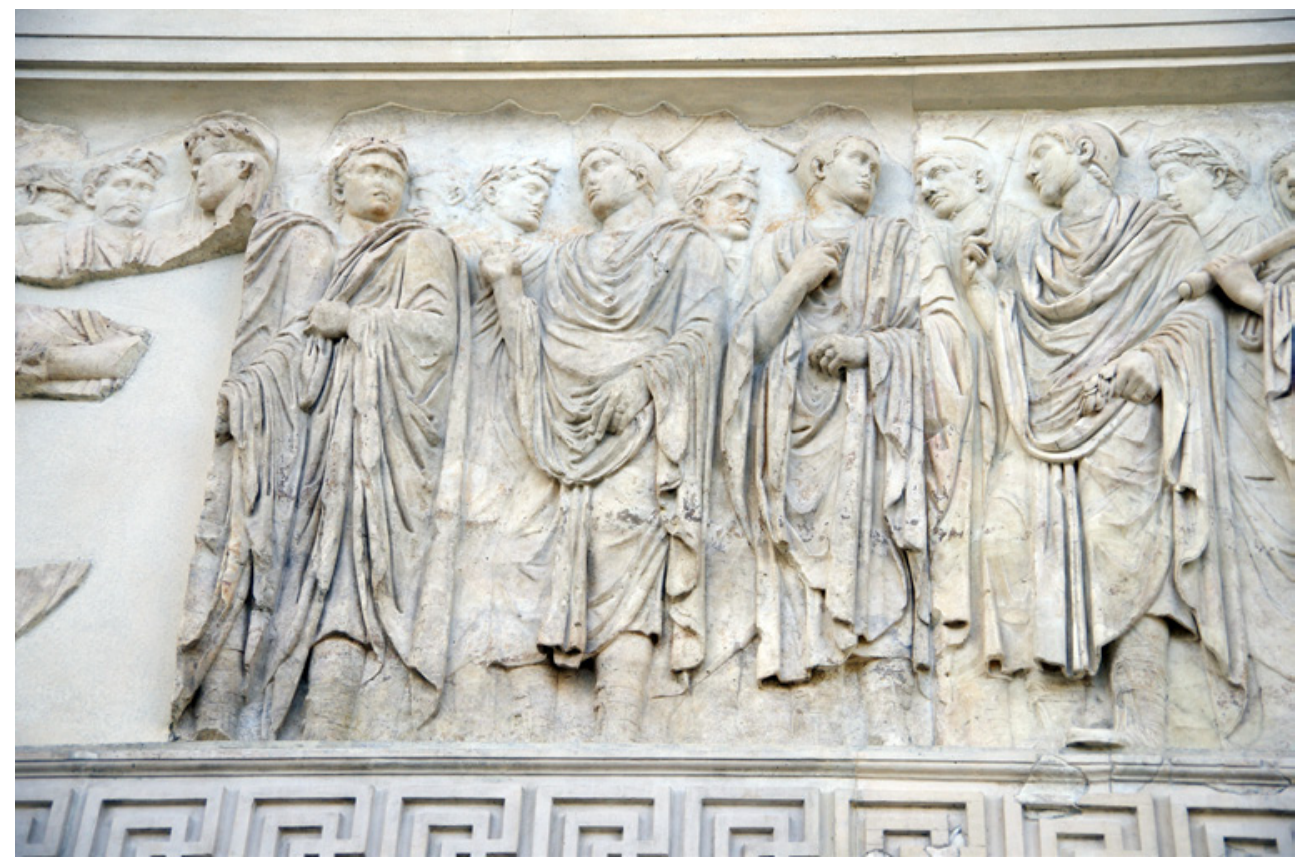

FIGURE 2.2 Augustus being depicted alongside senators in a sacrificial procession on the so-called Ara Pacis.

PHOTO BY THE AUTHOR.

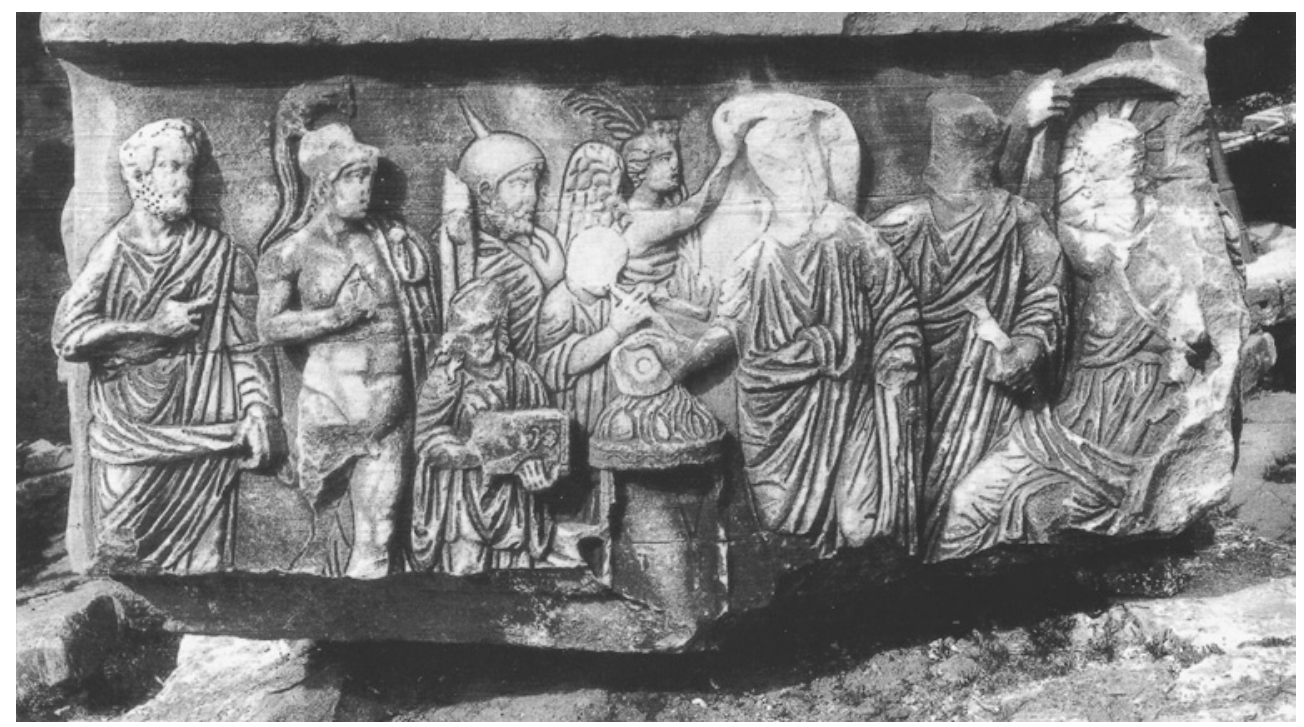

FIGURE 2.3 The Decennalia base showing the emperor sacrificing in the presence of the Genius (divine spirit) of the Senate. Source: DAI Rom: $35 \cdot 357$. 


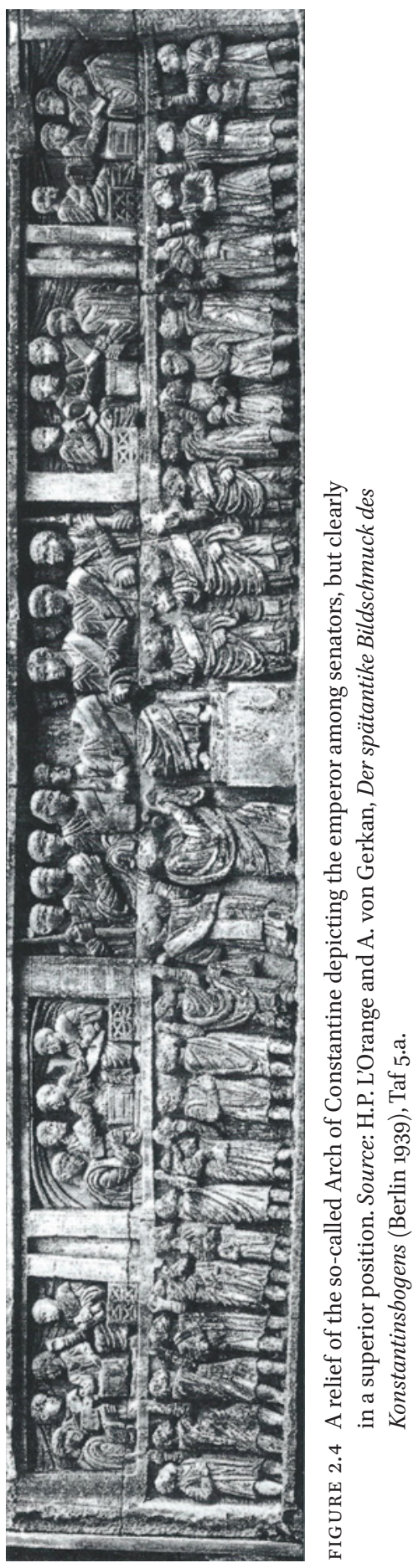


Finally, the ambiguous and shifting relation between emperor and senators also becomes clear from the way they are represented on coins. As late as 324 $\mathrm{AD}$, Constantine is regularly depicted wearing the senatorial toga, and small togate figures are still shown next to emperors on coins that are dated between $\mathrm{AD} 367-375 \cdot{ }^{29}$ Yet, clear numismatic depictions of senators or references to the senate in coin legends peter out after the late second century AD. ${ }^{30}$ From the third century onwards, the emperor is numismatically increasingly depicted in a military guise. ${ }^{31}$ Senatorial standing of the emperor can still be expressed by showing him wearing the toga, but senators are no longer visible on perhaps the most potent visual medium of antiquity.

The later period of the Roman Empire, from the late third century AD onwards, is sometimes described as the Dominate, from dominus 'master'. It is contrasted with the earlier period, called the Principate, from princeps 'first man' - the imperial form of address that denoted the emperor as most important senator. Yet, not even the emperors in the later Roman Empire ruled on their own. Nor could they wholly depend on their "personal people" in the way that a ruler like Haile Sellasie seems to have done. Even when senators had lost much of their actual power, the senate retained a potent symbolical function. Councillors may have been convened in a consistorium that was handpicked by the ruler and may have mainly rubberstamped imperial decision, but it was still important for the emperor to appear to consult his councillors, and to be shown in the senatorial toga. The distance between reality and representative claim had widened enormously over the centuries, but the representative claim was maintained. Roman emperors continued to rule in a senatorial world, at least symbolically.

\section{Bibliography}

Agamben, G., State of Exception (Chicago, 2005).

Boeft, J. den, J.W. Drijvers, D. den Hengst, and H. Teitler, Philological and Historical

Commentary on Ammianus Marcellinus XXX (Leiden, 2015).

CIL = Corpus Inscriptionum Latinarum (1893-).

29 RIC VII, Antioch, nos. 39-41, 46; RIC IX, Antioch, nos. 20a-f.

$3^{0}$ RIC III Commodus, nos. 194, 538, 549 for the emperor clasping hands with a senator/ genius of the Senate; a coin from $\mathrm{AD} 213$, from the reign of Caracalla, is the last to show the legend Genio SENATVs with an image of the genius of the Senate: RIC IV Caracalla, no. 234 .

$31 \quad$ Manders (2012) 63-94. 
Cooley, A., Res Gestae Divi Augusti: Text, Translation, and Commentary (Cambridge, Eng., 2009).

Crook, J., Consilium Principis. Imperial Councils and Counsellors from Augustus to Diocletian (Cambridge, Eng., 1955).

Eck, W., "The Emperor and his Advisers," in A. Bowman, P. Garnsey, and D. Rathbone (eds.), The Cambridge Ancient History 11, 2nd ed. (Cambridge, Eng., 2000), 195-213.

Eck, W., "Der Kaiser, die Führungsgeschichten, und die Administration des Reiches," in W. Eck (ed.), Die Verwaltung des römischen Reiches in der hohen Kaiserzeit, vol. 2, (Basel, 1997), 3-145.

Gibbon, E., The History of the Decline and Fall of the Roman Empire, vol. 1 (London, 1776).

Halfmann, H., Itinera principum: Geschichte und Typologie der Kaiserreisen im römischen Reich (Stuttgart, 1986).

Halfmann, H., Die Senatoren aus dem östlichen Teil des Imperium Romanum bis zum Ende des 2.Jh. n. Chr. (Göttingen, 1979).

Hekster, O., "Imagining power. Reality gaps in the Roman Empire," in BABESCH 86 (2011), 111-124.

Hekster, O., and W. Rich, "Octavian and the Thunderbolt: The Temple of Apollo Palatinus and Roman Traditions of Temple Building," in The Classical Quarterly 56 (2006), 149-168.

Hodgson, L., Res Publica and the Roman Republic: 'Without Body or Form' (Oxford, 2016). Kapuscinski, R., The Emperor. The Downfall of an Autocrat (New York, 1978).

Kraus, C., and A. Woodman, Latin Historians (Oxford, 1997).

Kuhn-Chen, B., Geschichtskonzeptionen griechischer Historiker im 2. und 3. Jahrhundert n. Chr. (Frankfurt am Main, 2002).

Manders, E., Coining Images of Power. Patterns in Representation of Roman Emperors on Imperial Coinage, AD 193-284 (Leiden, 2012).

Michel, A-C., La cour sous l'empereur Claude: les enjeux d'un lieu de pouvoir (Rennes, 2015).

Millar, F., The Emperor in the Roman World, 31 BC - AD 337, 2nd ed. (London, 1992).

Millar, F., "State and Subject: The Impact of Monarchy," in F. Millar and E. Segal (eds.), Caesar Augustus. Seven Aspects (Oxford, 1984), 37-60.

Näf, B., Senatorisches Standesbewusstsein in spätrömischer Zeit (Freiburg, 1995).

Raimondi Cominesi, A., "Augustus in the Making. A Reappraisal of the Ideology behind Octavian's Palatine Residence through its Interior Decoration and Topographical Context," in Latomus 77 (2018), 704-735.

Rowe, G., "Reconsidering the Auctoritas of Augustus," in Journal of Roman Studies 103 (2013), 1-15.

Scheithauer, A., Kaiserbild und literarisches Programm. Untersuchungen zur Tendenz der Historia Augusta (Frankfurt am Main, 1987). 
RIC = Roman Imperial Coinage (1923-).

Talbert, R., "The Senate and Senatorial and Equestrian Posts," in A. Bowman, E. Champlin, and A. Lintott (eds.), The Cambridge Ancient History, vol. 10, 2nd ed. (Cambridge, Eng., 1996), 324-343.

Wiedemann, T., "Tiberius to Nero," in A. Bowman, E. Champlin, and A. Lintott (eds.), The Cambridge Ancient History, vol. 10, 2nd ed. (Cambridge, Eng., 1996), 198-255.

Winterling, A., Aula Caesaris. Studien zur Institutionalisierung des römischen Kaiserhofes in der Zeit von Augustus bis Commodus (3r v. Chr. - 192 n. Chr.) (Munich, 1999).

Zanker, P., Die Apotheose der römischen Kaiser (Munich, 2004).

Zanker, P., Augustus und die Macht der Bilder (Munich, 1987).

Zink, S., and H. Piening, "Haec aurea templa: the Palatine temple of Apollo and its Polychromy," in Journal of Roman Archaeology 22 (2009), 109-122. 